\title{
Changes in the density and localisation of endothelin receptors in the early stages of rat diabetic retinopathy and the effect of insulin treatment
}

\author{
J. A. De Juan, F.J. Moya, A. Ripodas, R. Bernal, A. Fernandez-Cruz, R. Fernandez-Durango \\ Laboratory of Diabetes, Department of Internal Medicine III, Hospital Clinico San Carlos, Madrid, Spain
}

\section{Abstract}

Aims/hypothesis. The endothelin system (ET system) has been implicated in the retinal blood flow abnormalities that precede the onset of diabetic retinopathy. This study was undertaken to assess whether the density and localisation of both the immunoreactive endothelin-1 and endothelin receptors in rat retina change in the early stages of diabetes and the insulin treatment would affect those changes.

Methods. Untreated streptozotocin-diabetic, insulintreated streptozotocin-diabetic and age-matched control rats were killed 15, 45 and 90 days after the induction of diabetes. Binding assays were used to determine the density and proportion of endothelin receptors in neural retinal membranes. Localisation of endothelin receptors and immunoreactive endothelin-1 were analysed by microautoradiography and immunohistochemistry, respectively.

Results. Fifteen days after the induction of diabetes, the neural retinal membranes of untreated streptozotocin-diabetic rats showed a statistically significant decrease in the density of both endothelin receptor subtypes when compared with age-matched control rats. At 90 days, however, the density of endothelin receptors type B was statistically significantly higher than that of control rats, and the innermost layers of the diabetic retina also showed an increase of both endothelin receptor type $\mathrm{B}$ receptor and immunoreactive endothelin-1 signal. Insulin treatment during 90 days up-regulated endothelin receptor type $\mathrm{A}$ in neural retinal membranes and in the innermost layers of the retina when compared with control retinas. Conclusion/interpretation. These results show that the endothelin system is altered in both vascular and neuronal components of the retina in early diabetic retinopathy. The up-regulation of endothelin receptor type $\mathrm{A}$ induced by insulin treatment suggests that insulin might be involved in retinal microangiopathy. [Diabetologia (2000) 43: 773-785]

Keywords Endothelin, endothelin receptors, insulin, retinopathy.
Received: 12 October 1999 and in revised form: 27 January 2000

Corresponding author: R. Fernandez-Durango, Department of Internal Medicine III, Hospital Clinico San Carlos, C/Martin Lagos s/n, 28040 Madrid, Spain

Abbreviations: BQ123, cyclic pentapeptide (ciclo-(D-Asp-ProD-Val-Leu-D-Trp); Ch, choroid; DAB, diaminobenzidine; DSS, disuccinimidyl suberate; ET, endothelin; ETA, endothelin receptor type A; ETB, endothelin receptor type B; GCL, ganglion cell layer, IR-, immunoreactive-; IN, inner nuclear layer; IPL, inner plexiform layer; $\mathrm{NO}$, nitric oxide; $\mathrm{ON}$, outer nuclear layer; OPL, outer plexiform layer; RCL, rods and cones layer; S6c, sarafotoxin 6c; STZ, streptozotocin; $\mathrm{K}_{\mathrm{d}}$, dissociation constant; Bmax, receptor density.
The endothelins (ETs) are a family of $2500 \mathrm{M}_{\mathrm{r}}$ peptides with three distinct isoforms, endothelin-1, -2 and -3 (ET-1, ET-2 and ET-3) [1,2]. ET-1 is a potent vasoconstrictor produced by endothelial cells that also induces mitogenesis in vascular smooth muscle cells $[1,3]$. Two major types of ET receptors, termed endothelin receptor type A (ETA) and endothelin receptor type B (ETB) have been identified, cloned and sequenced in mammals $[4,5]$. The ETA receptor mediates most of the vasoconstrictor action of ET-1 and has selective affinity for ET-1 [6]. The ETB receptor has equal affinities for all ET isoforms and has been shown to release endothelium-derived nitric 
oxide (NO) and prostacyclin which induce vasodilatation [7]. In some vascular beds, the ETBs possibly also mediate vasoconstriction [8] and play a part in clearance of ETs from circulation by endothelial cells [9].

In the retina, immunoreactive ET-1 (IR-ET-1), and ET-3 (IR-ET-3) have been found in human, rat, and rabbit retinal extracts [10-12], and ET-1 and ET3 mRNA expression has been detected in the whole rat retina [13]. Immunoreactive ET-1 has been localised in the different layers of human and rat retina $[14,15]$. We have previously reported the presence of ETA and ETB binding sites in neural retinal membranes [11]. On the other hand, ETA and ETB mRNA expression has been detected in the rat retina [13], and autoradiographic studies have shown that ETA and ETB receptors are present in the retinal blood vessels and the neural retina of human and rabbit eyes [16].

The ocular application of ET-1 causes retinal vasoconstriction and decreases retinal blood flow [17]. The retinal blood flow appears to be altered in animals studies with a short duration of diabetes, these haemodynamic changes being related to the development of diabetic retinopathy [17-19]. Moreover, experimental evidence has been provided in support of the hypothesis that ET-1 is involved in the regulation of retinal blood flow in normal physiologic situations and that an increase in the endogenous expression of ET-1 contributes to the reduction of retinal blood flow reported in the early stages of diabetes in rats [20].

Several studies have shown that insulin and ETs interact in a complex manner. Insulin activated ET-1 synthesis and secretion in cultured endothelial cells [21], whereas in vascular smooth muscle cells and pericytes insulin increased the ETA receptor subtype density and the expression of ETA receptor mRNA $[22,23]$. In vivo studies have shown that insulin treatment normalised the retinal blood flow [24], mainly influencing ET-1 action and NO production [25, 26].

All these observations suggest that the ET system (ETs and their receptors) plays a part in the retinal blood flow changes which precede the development of diabetic retinopathy. It is still not known, however, whether the localisation of both the ET- 1 and its receptors change in the diabetic retina. For these reasons this study investigated: 1) the localisation of ET receptors and IR-ET-1 in the different layers of the rat retina, 2) whether the density and localisation of retinal ET receptors and IR-ET-1 change in the early stages of diabetes and 3 ) the putative effect of insulin treatment on the ET system in the retina of diabetic rats.

\section{Materials and methods}

We obtained ET-1, ET-3, cyclic pentapeptide (BQ123), sarafotoxin 6c (S6c) and rabbit anti ET-1 polyclonal antibody from Peninsula Laboratories (Merseyside, UK). Amersham International (Buckinghamshire, UK) supplied ${ }^{125} \mathrm{I}-\mathrm{ET}-1$ and ${ }^{125} \mathrm{I}-$ ET-3 (2000 Ci/mmol) and the photographic emulsion for autoradiography. Whatman $\mathrm{GF} / \mathrm{C}$ filters were from Whatman International (Maidstone, UK). Streptozotocin (STZ) was obtained from Sigma Chemical (St. Louis, Mo., USA). The SepPak C-18 cartridges were from Waters Associates (Milford, Mo., USA). Insulin (bovine/porcine) was Lente from NovoNordisk (Bagsvard, Denmark). Rabbit anti human factor VIII polyclonal antibody and the "supersensitive immunodetection system" kit for the immunohistochemical development were obtained from Biogenex (San Ramon, Calif., USA). All other chemicals used were high-grade commercially available products.

Experimental animals. Two-month-old male Wistar rats (200 g body weight) were housed and handled according to the European Community Council Directive of 24 November 1986 (86/ $609 / \mathrm{ECC}$ ). Animals were divided into three groups: 1 ) untreated STZ-diabetic rats $(n=40), 2)$ insulin-treated STZ-diabetic rats $(n=40)$, and 3$)$ age-matched control rats $(n=40)$. Diabetes was induced with a single i.p. injection of STZ $(75 \mathrm{mg} / \mathrm{kg}$ body weight) in $10 \mathrm{mmol} / \mathrm{l}$ citrate buffer $\mathrm{pH} 4.5$. Only agematched control rats were injected with the same volume of vehicle. Three days after diabetes induction, 40 diabetic rats were injected s.c. with insulin once daily. The insulin injection was given at $1000 \mathrm{~h}$ with the dose adjusted to achieve normoglycaemia (3 to 6 units of insulin). The animals were kept in a temperature-controlled room on a 12-h light:dark cycle and fed according to appetite. Weights and blood glucose were monitored three times a week, with all untreated STZ-diabetic rats having blood glucose concentrations higher than $25 \mathrm{mmol} / \mathrm{l}$ and insulin treated STZ-diabetic rats having a glucose concentration of 7.8 to $10.5 \mathrm{mmol} / \mathrm{l}$. The animals were killed by decapitation 15 (12 rats per group), 45 (12 rats per group) or 90 days (16 control, 14 untreated STZ-diabetic, and 16 insulin-treated STZ-diabetic rats) after the injection of STZ or vehicle. In addition, a group of 40 rats that had remained normoglycaemic despite STZ injection were also killed by decapitation (blood glucose $7.17 \pm 0.45 \mathrm{mmol} / \mathrm{l})$ to evaluate the effect of STZ injection by itself (at days 15, 45 and 90 in groups of 12,12 and 16 respectively). In all groups, retinas from 12 rats were dissected and homogenised rapidly for membrane preparation. In each experimental group, four collections of pooled retinas from three rats were analysed and compared. Four eyes from each experimental 90-day group were frozen in 2-methyl-butane on liquid nitrogen and stored at $-80^{\circ} \mathrm{C}$ for microautoradiography and immunohistochemistry experiments.

Insulin and ET-1 radioimmunoassays. Blood samples were collected in chilled tubes containing protease inhibitors and centrifuged at $1000 \mathrm{~g}$ for $30 \mathrm{~min}$ at $4^{\circ} \mathrm{C}$. Plasma was immediately frozen at $-20^{\circ} \mathrm{C}$ until assayed. Plasma insulin concentrations were determined by RIA as described previously [27]. The ET-1 extraction with Sep-Pack C18 cartridge and the measurement of IR-ET-1 were done as published previously [12]. The ET-1 antibody reacts $100 \%$ with ET-1 and cross-reacts $7 \%$ with ET-2, $7 \%$ with ET-3, 35\% with porcine big-ET-1 and $15 \%$ with human big-ET-1. It did not show any cross-reactivity with unrelated peptides like somatostatin, vasopressin, insulin or atrial natriuretic peptide. 
Rat retinal particulate preparations and binding assays. Rat retinal particulate preparations were done as reported previously [28]. Briefly, rat retinas were dissected and homogenised in $5 \mathrm{mmol} / \mathrm{l}$ TRIS-HCl pH 7.4 buffer containing protease inhibitors. The homogenates were centrifuged at $600 \mathrm{~g}$ for $15 \mathrm{~min}$ at $4^{\circ} \mathrm{C}$. The obtained supernatants were recentrifuged twice at $30000 \mathrm{~g}$ for $30 \mathrm{~min}$ at $4{ }^{\circ} \mathrm{C}$. The pellets were resuspended in $50 \mathrm{mmol} / \mathrm{l}$ TRIS-HCl pH 7.4 buffer, stored in aliquots at $-70^{\circ} \mathrm{C}$ and used within 1 month. Samples of the retinal particulate preparations were analysed for immunolocalisation of the Factor VIII-related antigen to verify the absence of vascular contamination as described previously [11].

The binding assays were carried out according to the method already published $[11,12]$. Retinal membrane preparations (6-20 $\mu \mathrm{g}$ of protein) were incubated for $120 \mathrm{~min}$ at $25^{\circ} \mathrm{C}$ with ${ }^{125}$ I-ET-1 or ${ }^{125}$ I-ET-3 (2 to $100 \mathrm{pmol} / \mathrm{l}$ ) in saturation experiments. The proportion of ET receptor subtypes was calculated by doing binding studies with ${ }^{125}$ I-ET-1 or ${ }^{125}$ I-ET-3 (40 pmol/l) in the absence or presence of S6c $(0.1 \mu \mathrm{mol} / 1)$ or of BQ123 $(1 \mu \mathrm{mol} / \mathrm{l})$. Considering that the ${ }^{125} \mathrm{I}-\mathrm{ET}-1$ specific binding represents $100 \%$ of the receptor whereas the remaining proportion of ${ }^{125}$ I-ET-1 specific binding in the presence of BQ123 is the proportion of ETA receptor and the remaining proportion of ${ }^{125}$ I-ET-1, specific binding in the presence of S6 $\mathrm{c}$ is the proportion of ETB receptor. Four separate experiments were made in duplicate.

Affinity cross-linking and SDS-PAGE. These studies were done as described previously [12]. The labelled peptides (40 $\mathrm{pmol} / \mathrm{l})$ were incubated with retinal membrane particulate preparations ( $60 \mu \mathrm{g}$ of protein) and then cross-linked on receptors with $0.5 \mathrm{mmol} / \mathrm{l}$ disuccinimidyl suberate (DSS). SDSPAGE was done according to the method of Laemmli [29], using $10 \%$ SDS-polyacrylamide gels. Three independent experiments were carried out in duplicate.

Microautoradiography of ${ }^{125}$ I-ET-1 and ${ }^{125}$ I-ET-3 binding sites. The experimental procedure has been described elsewhere [30]. In brief, $12 \mu \mathrm{m}$-thick sections of the frozen eyes were incubated with $40 \mathrm{pmol} / \mathrm{l}{ }^{125} \mathrm{I}-\mathrm{ET}-1$ or ${ }^{125} \mathrm{I}$-ET-3 for $60 \mathrm{~min}$ at room temperature. The specific binding was determined by displacing the radioligand with $0.1 \mu \mathrm{mol} / 1 \mathrm{ET}-1$, ET-3, S6c or $1 \mu \mathrm{mol} / \mathrm{l} \mathrm{BQ123}$. After the standardisation of the illumination conditions, using set positions for diaphragm apertures and condenser, the posterior pole of the eyes was photographed with dark-field microscopy and then the slides were counterstained with toluidine blue and photographed with light-field microscopy. The negatives of the dark-field images were digitised and examined with a densitometric program (Image Master, Pharmacia, Uppsala, Sweden) to determine the optical density of the silver grains on a lane placed perpendicularly across the retina at a particular site. Three separate experiments were carried out in duplicate.

Immunohistochemical studies. Immunohistochemical studies were done on $12 \mu \mathrm{m}$-thick sections of the eyes thaw-mounted onto poly-L-Lysine treated slides. For human factor-VIII detection, the sections were fixed in cold acetone for $10 \mathrm{~min}$ and then in chloroform for $20 \mathrm{~min}$ at room temperature. To detect ET-1, the sections were fixed in $4 \%$ paraformaldehyde and $1 \%$ glutaraldehyde for $1 \mathrm{~h}$. The sections were incubated either for $30 \mathrm{~min}$ at $25^{\circ} \mathrm{C}$ with rabbit anti-human factor VIII polyclonal antibody diluted 1:200 in phosphate buffer $\mathrm{pH} 7.6$ containing $1 \% \mathrm{BSA}$, or for $40 \mathrm{~min}$ at $25^{\circ} \mathrm{C}$ with rabbit anti-ET-1 polyclonal antibody diluted 1:400 in the same buffer. Negative control slides were incubated with normal rabbit serum instead of the primary antisera. In all sections, immunostaining was de- veloped using "supersensitive immunodetection system" kit. A biotinylated goat anti-rabbit secondary antibody (1:400) was used and diaminobenzidine (DAB) was the chromogen for streptavidin-peroxidase. The slides were counterstained with toluidine blue and photographed by routine light microscopy. For the quantitative analysis of the immunohistochemistry results, images were captured using Leica Qwin image processing and analysis software (Leica microscopy systems, Heerbrugg, Switzerland) on a PC computer linked to a high resolution video camera (Leica DC100) mounted on a microscope. Three visual fields were sampled from the posterior pole of each eye. Within each visual field immunolabelling area and intensity were measured and compared in all the retinal layers.

Statistical analysis. The binding data for the determination of the density and affinity of binding sites were evaluated by computer-assisted non-linear regression analysis with the LIGAND program [31] after preliminary treatment of the data with the EBDA program [32]. The values are presented as means \pm SEM. Statistical significance was analysed by oneway-ANOVA and Bonferroni post-hoc test.

\section{Results}

Body weight, glucose concentrations and IR-insulin and IR-ET-1 plasma concentrations. The variables measured are shown in Table 1. Insulin treatment normalised the hyperglycaemia, the reduced body weight and the hypoinsulinaemia observed in the untreated STZ-diabetic rats. Plasma concentrations of IR-ET-1 were significantly increased in untreated STZ-diabetic rats compared with the age-matched control rats at 90 days after the induction of diabetes. By contrast, insulin-treated STZ-diabetic rats had plasma concentrations of IR-ET-1 no different from those of control rats at all studied times.

Immunohistochemistry. Factor VIII immunolocalisation: immunostaining appeared on the ganglion cell layer (GCL), on the inner plexiform layer (IPL) and on the outer plexiform layer (OPL) and also in the choroid of the three groups of rats showing similar intensity and distribution in the three groups of rats. Negative control sections, prepared by omission of the primary antibody, were free of labelling. Rat retinal particulate preparations were not immunoreactive in any of the three group of rats, indicating that our methodology eliminated most of the vascular tissue present in the retina (images not shown). Thus, from now we will refer to the retinal particulate preparations as "neural retinal membranes".

Endothelin-1-like immunolocalisation: In control rat retinas, immunostaining was mainly localised to the inner nuclear layer (IN), the IPL and the GCL of the retinas and also the choroid (Fig.1). Diabetes caused a strong up-regulation of IR-ET-1 in all above-cited retinal layers and also in the choroid. In addition, a new IR-ET-1 signal was localised in the rods and cones layer (RCL) of the retinas of untreat- 
Table 1. Glucose concentrations, body weight, and plasmatic IR-insulin and IR-ET-1 concentrations

\begin{tabular}{|c|c|c|c|c|c|}
\hline Experimental group & $\mathrm{n}$ & $\begin{array}{l}\text { Glucose } \\
(\mathrm{mmol} / \mathrm{l})\end{array}$ & $\begin{array}{l}\text { Body weight } \\
\text { (g) }\end{array}$ & $\begin{array}{l}\text { IR-insulin } \\
(\mathrm{pmol} / \mathrm{l})\end{array}$ & $\begin{array}{l}\text { IR-ET-1 } \\
(\mathrm{pmol} / \mathrm{l})\end{array}$ \\
\hline $\begin{array}{l}15 \text { days after STZ injection } \\
\text { Age-matched control rats } \\
\text { Untreated STZ-diabetic rats } \\
\text { Insulin-treated STZ-diabetic rats }\end{array}$ & $\begin{array}{l}12 \\
12 \\
12\end{array}$ & $\begin{aligned} 7.1 & \pm 0.3 \\
25 & \pm 1.6^{\mathrm{a}, \mathrm{b}} \\
10.8 & \pm 1.6\end{aligned}$ & $\begin{array}{l}288 \pm 4 \\
243 \pm 6 \\
282 \pm 2\end{array}$ & $\begin{array}{r}214 \pm 40 \\
21 \pm 3^{\mathrm{a}} \\
153 \pm 30\end{array}$ & $\begin{array}{l}2.29 \pm 0.24 \\
2.25 \pm 0.28 \\
1.97 \pm 0.20\end{array}$ \\
\hline $\begin{array}{l}45 \text { days after STZ injection } \\
\text { Age-matched control rats } \\
\text { Untreated STZ-diabetic rats } \\
\text { Insulin-treated STZ-diabetic rats }\end{array}$ & $\begin{array}{l}12 \\
12 \\
12\end{array}$ & $\begin{array}{c}6.9 \pm 0.3 \\
23.9 \pm 1.6^{\mathrm{a}, \mathrm{b}} \\
9.2 \pm 2.6\end{array}$ & $\begin{array}{l}415 \pm 9^{\mathrm{c}} \\
243 \pm 9^{\mathrm{a}, \mathrm{b}} \\
385 \pm 4^{\mathrm{c}}\end{array}$ & $\begin{array}{r}278 \pm 54 \\
22 \pm 7^{a} \\
143 \pm 25\end{array}$ & $\begin{array}{r}1.97 \pm 0.16 \\
2.2 \pm 0.16 \\
1.8 \pm 0.12\end{array}$ \\
\hline $\begin{array}{l}90 \text { days after STZ injection } \\
\text { Age-matched control rats } \\
\text { Untreated STZ-diabetic rats } \\
\text { Insulin-treated STZ-diabetic rats }\end{array}$ & $\begin{array}{l}16 \\
14 \\
16\end{array}$ & $\begin{array}{l}6.8 \pm 0.5 \\
30.7 \pm 1.5^{\mathrm{a}, \mathrm{b}} \\
8.1 \pm 1.8\end{array}$ & $\begin{array}{l}468 \pm 11^{\mathrm{c}} \\
237 \pm 10^{\mathrm{a}, \mathrm{b}} \\
442 \pm 14^{\mathrm{c}}\end{array}$ & $\begin{aligned} 261 & \pm 50 \\
22 & \pm 6^{\mathrm{a}} \\
138 & \pm 30\end{aligned}$ & $\begin{array}{l}1.96 \pm 0.12 \\
2.73 \pm 0.12^{\mathrm{a}, \mathrm{b}} \\
1.93 \pm 0.12\end{array}$ \\
\hline
\end{tabular}

Glucose concentrations, body weight, and plasma IR-insulin and IR-ET- 1 concentrations on days 15, 45 and 90 after injection of $75 \mathrm{mg} \mathrm{STZ} / \mathrm{kg}$ body weight or vehicle in control, untreated STZ-diabetic and insulin-treated STZ-diabetic rats. The values are means \pm SEM. ${ }^{a} p<0.05$ vs age-matched con-

ed STZ-diabetic rats. Moreover, the pattern of IRET-1 in the retinas from insulin-treated STZ-diabetic rats was similar to those of control rats, although the

Fig. 1. ET-1 (A-C) and factor VIII-related antigen (D-F) immunohistochemistry in the retina of control $(\mathbf{A}, \mathbf{D})$, untreated STZ-diabetic $(\mathbf{B}, \mathbf{E})$ and insulin-treated STZ-diabetic $(\mathbf{C}, \mathbf{F})$ rats 90 days after the induction of diabetes. Biotinylated goat anti-rabbit secondary antibody was used and diaminobenzidine was the chromogen for streptavidin-peroxidase. Negative control sections, prepared by omission of the primary antibody (incubated with normal rabbit serum), were free of labelling (images not shown). The slides were counterstained with toluidine blue and photographed by routine light microscopy $(\mathrm{S}$, sclera; Ch, choroid; RCL, rods and cones layer; ON, outer nuclear layer; IN, inner nuclear layer; IPL, inner plexiform layer; GCL, ganglion cell layer). (Original magnification $\times 80$ ) trol rats at the same time-point; ${ }^{\mathrm{b}} p<0.05$ vs insulin-treated STZ-diabetic rats at the same time-point; ${ }^{\mathrm{c}} p<0.05$ vs 15 days in the same experimental group; ${ }^{\mathrm{d}} p<0.05$ vs 45 days in the same experimental group (one way ANOVA and Bonferroni post hoc test)

intensity of the immunolabelling was higher than in the retinas of the control rats. Sections incubated with normal serum showed no specific labelling.

Binding experiments. The non-specific binding was in all cases less than $10 \%$ of the total binding. Unla-

Fig. 2. Saturation curves (small graphs) and their corresponding Scatchard plots (large graphs) for ${ }^{125}$ I-ET-1 (left column) and ${ }^{125}$ I-ET-3 (right column) in a representative experiment using neural retinal membranes from control (GC; $)$, untreated STZ-diabetic (GD; $\boldsymbol{\nabla}$ ) and insulin-treated STZ-diabetic (GT; $\nabla)$ rats, 15 (A and $\mathbf{B}), 45(\mathbf{C}$ and $\mathbf{D})$ and 90 (E and $\mathbf{F})$ days after STZ injection. Data points are means of duplicate measurements in a representative experiment
A

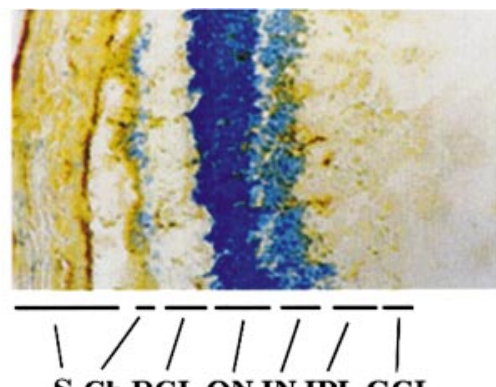

S Ch RCL ON IN IPL GCL

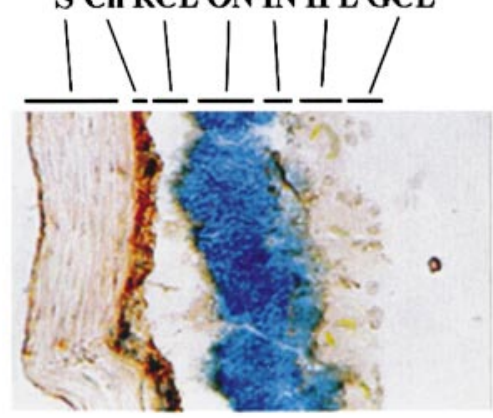

B

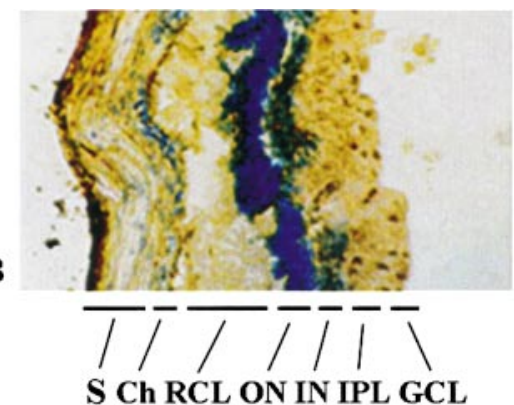

$\mathbf{E}$

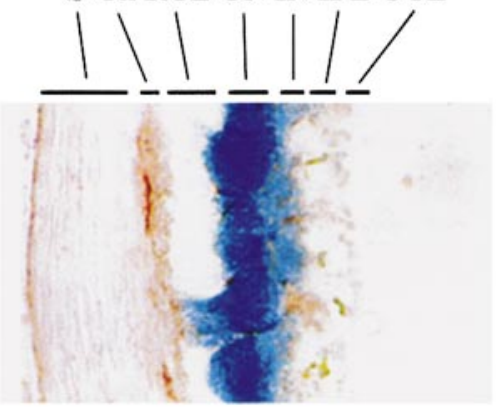

C

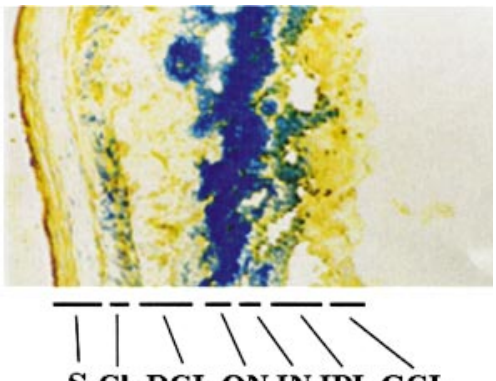
S Ch RCL ON IN IPL GCL

$\mathbf{F}$

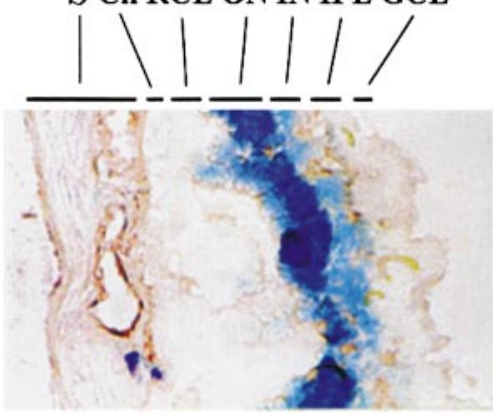




$$
{ }^{125} \mathrm{I}-\mathrm{ET}-1
$$
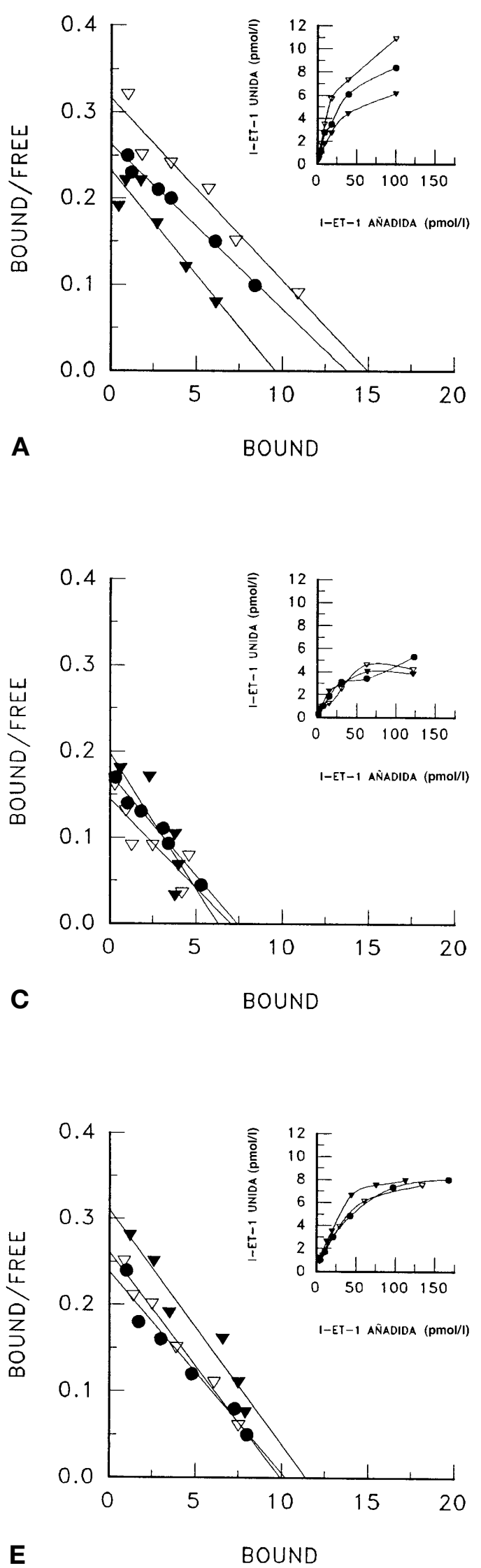

${ }^{125} \mathrm{I}-\mathrm{ET}-3$

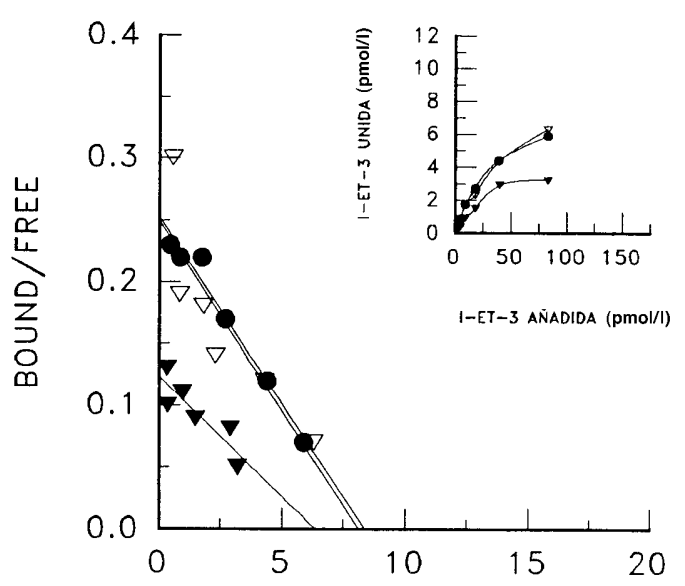

B

BOUND
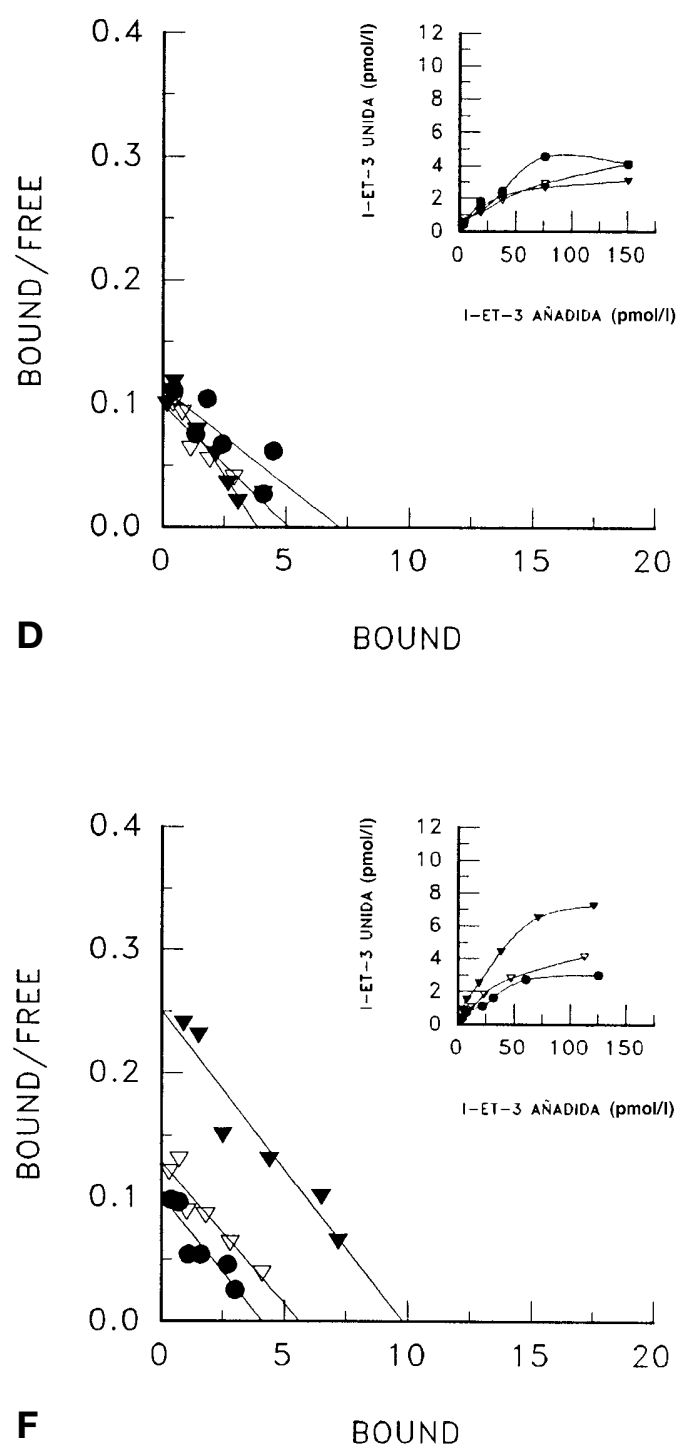
belled ET-1 or ET-3, $0.1 \mu \mathrm{mol} / 1$ completely displaced ${ }^{125}$ I-ET-1 and ${ }^{125}$ I-ET-3 binding. Non-related hormones like somatostatin, atrial natriuretic factor (ANF), or insulin, however did not have any effect on the binding.

Saturation experiments. Figure 2 shows the saturation curves and their corresponding Scatchard plots using ${ }^{125}$ I-ET-1 and ${ }^{125}$ I-ET-3 in a representative experiment using retinal membranes from the three groups of rats. Hill coefficients for both labelled hormones were not significantly different from 1 in all cases $(n=4)$. Dissociation constant $\left(\mathrm{K}_{\mathrm{d}}\right)$ and receptor density (Bmax) values are summarised in Table 2 .

The time course of changes in Bmax values after the induction of diabetes is shown in Figure 3. The values for ${ }^{125}$ I-ET-1 (Fig. 3A) diminished with the age of animals only in control rats, being significantly higher $(p<0.05)$ at 15 days than at 90 days after vehicle injection. Comparing the results from the three groups of animals at each studied time, at 15 days after STZ injection the Bmax values were significantly lower in untreated STZ-diabetic rats than those of age-matched control rats. At 45 or 90 days after the induction of diabetes, however, no significant differences were found between the three groups of animals.

The Bmax values for ${ }^{125}$ I-ET-3 (Fig. 3B) in control and insulin-treated STZ-diabetic rats diminished with age, being significantly higher $(p<0.05)$ at either 15 or 45 than at 90 days after vehicle or STZ injection. In untreated STZ-diabetic rats, the values increased with the age of the rats, being significantly lower at 15 than at either 45 or 90 days. Comparing the results from the three groups of animals at each studied time, at 15 days after STZ injection, the Bmax values were significantly lower in untreated
STZ-diabetic rats than those of control and insulintreated STZ-diabetic rats. At 45 days, however, no significant differences were found between the three groups of animals. Moreover, at 90 days, the Bmax values were significantly higher in untreated STZ-diabetic rats than those of control and insulin-treated STZ-diabetic rats.

Competition experiments. Figure 4A shows that the proportion of ETA diminished with age only in the untreated STZ-diabetic rats, being significantly higher $(p<0.05)$ at either 15 or 45 than those at 90 days after the induction of diabetes. Comparing the results from the three group of animals at each time, at either 15 or 45 days after vehicle or STZ injection, no significant difference was found. At 90 days, however, the proportion of ETA was significantly lower in untreated STZ-diabetic rats than that of age-matched control rats.

Figure 4B shows that the proportion of ETB in control and insulin-treated STZ-diabetic rats diminished with age, although no significant differences were found. In contrast, in untreated STZ-diabetic rats it increased with the age of the rats, being significantly lower at 15 than at 90 days after the induction of diabetes. On the other hand, the proportion of ETB in untreated STZ-diabetic rats at 90 days was significantly higher than that of age-matched control rats.

The specific binding of ${ }^{125}$ I-ET-3 to the neural retinal membranes was totally displaced by S6c, whereas the BQ123 did not affect this binding, which shows that at the concentrations used the ${ }^{125}$ I-ET-3 binds only to the ETB receptors.

Affinity cross-linking experiments. Preincubation of rat retinal membranes with ${ }^{125}$ I-ET-1 (Fig.5A) or

Table 2. Saturation experiments

\begin{tabular}{|c|c|c|c|c|}
\hline \multirow[t]{2}{*}{ Experimental group } & \multicolumn{2}{|l|}{${ }^{125} \mathrm{I}-\mathrm{ET}-1$} & \multicolumn{2}{|l|}{${ }^{125}$ I-ET-3 } \\
\hline & $\mathrm{Kd}(\mathrm{pmol} / \mathrm{l})$ & Bmax (fmol/mg prot.) & $\mathrm{Kd}(\mathrm{pmol} / \mathrm{l})$ & Bmax (fmol/mg prot.) \\
\hline $\begin{array}{l}15 \text { days after STZ injection } \\
\text { Age-matched control rats } \\
\text { Untreated STZ-diabetic rats } \\
\text { Insulin-treated STZ-diabetic rats }\end{array}$ & $\begin{array}{l}61 \pm 12 \\
47 \pm 13 \\
65 \pm 16\end{array}$ & $\begin{array}{l}198 \pm 15 \\
119 \pm 24^{\mathrm{a}} \\
175 \pm 15\end{array}$ & $\begin{array}{l}57 \pm 10 \\
52 \pm 8 \\
66 \pm 8\end{array}$ & $\begin{aligned} 106 & \pm 5.7 \\
83 & \pm 5.6^{\mathrm{a}, \mathrm{b}} \\
110 & \pm 7.8\end{aligned}$ \\
\hline $\begin{array}{l}45 \text { days after STZ injection } \\
\text { Age-matched control rats } \\
\text { Untreated STZ-diabetic rats } \\
\text { Insulin-treated STZ-diabetic rats }\end{array}$ & $\begin{array}{l}61 \pm 8 \\
49 \pm 6 \\
38 \pm 5\end{array}$ & $\begin{array}{l}150 \pm 35 \\
143 \pm 21 \\
164 \pm 26\end{array}$ & $\begin{array}{l}44 \pm 6 \\
46 \pm 9 \\
56 \pm 6\end{array}$ & $\begin{aligned} 98 & \pm 13 \\
120 & \pm 15^{\mathrm{c}} \\
113 & \pm 16\end{aligned}$ \\
\hline $\begin{array}{l}90 \text { days after STZ injection } \\
\text { Age-matched control rats } \\
\text { Untreated STZ-diabetic rats } \\
\text { Insulin-treated STZ-diabetic rats }\end{array}$ & $\begin{array}{l}63 \pm 3 \\
51 \pm 4 \\
57 \pm 3\end{array}$ & $\begin{array}{l}131 \pm 15^{\mathrm{c}} \\
141 \pm 25 \\
171 \pm 21\end{array}$ & $\begin{array}{l}41 \pm 3 \\
40 \pm 4 \\
52 \pm 6\end{array}$ & $\begin{array}{c}54 \pm 7^{\mathrm{c}, \mathrm{d}} \\
110 \pm 20^{\mathrm{a}, \mathrm{b}} \\
66 \pm 9^{\mathrm{c}, \mathrm{d}}\end{array}$ \\
\hline
\end{tabular}

$\mathrm{K}_{\mathrm{d}}$ (dissociation constant) and Bmax (receptor density) for ${ }^{125}$ I-ET-1 and ${ }^{125}$ I-ET-3 in saturation binding experiments in control, untreated STZ-diabetic and insulin-treated STZ-diabetic rats. The values are means \pm SEM from five experiments done in duplicate and analysed by the LIGAND program
$[31,32] .{ }^{a} p<0.05$ vs age-matched control rats at the same time-point; ${ }^{\mathrm{b}} p<0.05$ vs insulin-treated STZ-diabetic rats at the same time-point; ${ }^{\mathrm{c}} p<0.05$ vs 15 days in the same experimental group; ${ }^{\mathrm{d}} p<0.05$ vs 45 days in the same experimental group (one way ANOVA and Bonferroni post hoc test) 

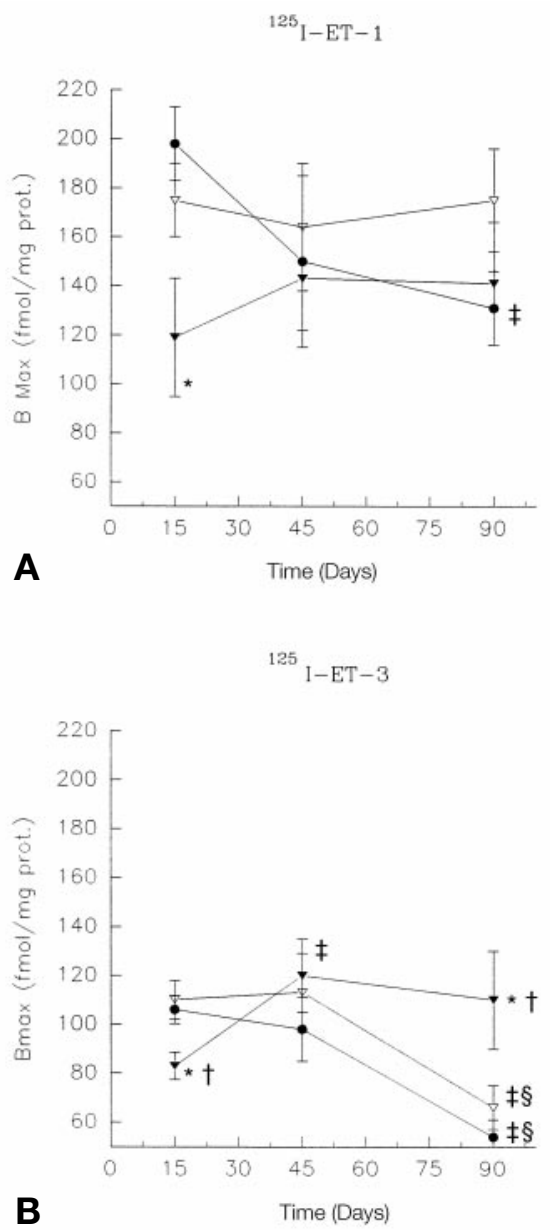

Fig.3. Graphic representation of Bmax values from saturation experiments in control $(\mathbf{O})$, untreated STZ-diabetic $(\boldsymbol{\nabla})$ and insulin-treated STZ-diabetic $(\nabla)$ rats. The values are mean$\mathrm{s} \pm \mathrm{SEM}$ from four experiments done in duplicate and analysed by the LIGAND program $[31,32] . * p<0.05$ vs age-matched control rats at the same time-point; ${ }^{\dagger} p<0.05$ vs insulintreated STZ-diabetic rats at the same time-point; ${ }^{\ddagger} p<0.05$ vs day 15 in the same experimental group; ${ }^{\S} p<0.05$ vs day 45 in the same experimental group; (one-way ANOVA and Bonferroni post hoc test)

${ }^{125}$ I-ET-3 (Fig. 5B) followed by cross-linking with DSS and SDS-PAGE resulted in the identification of two bands, having molecular masses of 52000 and 34 $000 \mathrm{M}_{\mathrm{r}}$ for both labelled hormones in the three groups of rats at 90 days after the induction of diabetes. The bands were abolished completely when the binding was conducted in the presence of $0.1 \mu \mathrm{mol} / 1$ unlabelled ET-1 or ET-3, respectively.

Microautoradiography. Figures 6 and 7 show darkfield and bright-field photomicrographs of rat retinal sections incubated in the presence of ${ }^{125}$ I-ET- 1 and ${ }^{125}$ I-ET-3, respectively. In all sections, the choroid showed a great density of silver grain without relevant differences between the three groups of rats.

Microautoradiography of ${ }^{125}$ I-ET-1 binding sites: labelling was found in all layers of the retinas from
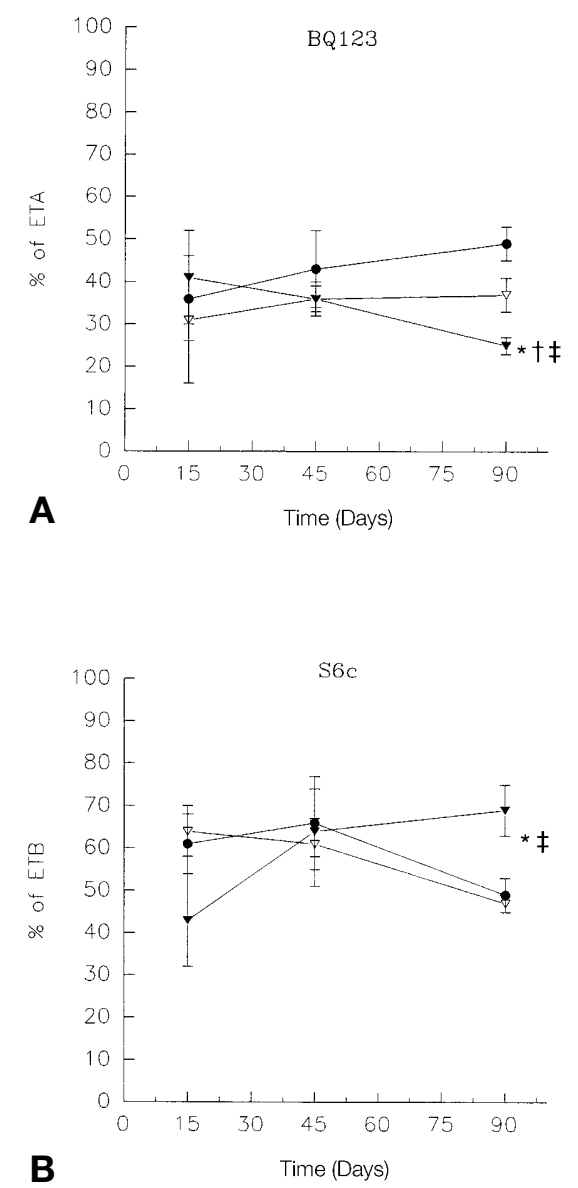

Fig. 4. Graphic representation of the proportions of ETA and ETB receptors calculated using BQ123 and S6c as competitors for the ${ }^{125} \mathrm{I}-\mathrm{ET}-1$ binding sites in neural retinal membranes in control ( $)$, untreated STZ-diabetic $(\boldsymbol{\nabla})$ and insulin-treated STZ-diabetic $(\nabla)$ rats. The values are means \pm SEM from four experiments done in duplicate. $* p<0.05$ vs age-matched control rats at the same time-point; ${ }^{\dagger} p<0.05$ vs insulin-treated STZ-diabetic rats at the same time-point; ${ }^{\ddagger} p<0.05$ vs day 15 in the same experimental group; ${ }^{\S} p<0.05$ vs day 45 in the same experimental group; (one-way ANOVA and Bonferroni post hoc test)

control rats (Fig. 6B) being more abundant in the innermost layers (IN, IPL, and GCL). The retinas from untreated STZ-diabetic rats (Fig. 6G) showed a similar pattern even though the silver grains on the GCL appeared assembled and forming clusters. In the retinas from insulin-treated STZ-diabetic rats (Fig. 6L), however, an intense labelling appeared in the RCL and in the OPL. Moreover, the GCL of these retinas also presented a greater density of silver grains similar to those of the control retinas. The labelling was specific since $0.1 \mu \mathrm{mol} / 1$ ET-1, (Fig. 6C,H,M), completely eliminated the silver grains.

In the sections incubated with ${ }^{125}$ I-ET-1 in the presence of $0.1 \mu \mathrm{mol} / 1 \mathrm{~S} 6 \mathrm{c}$ (Fig. 6D,I,N), the silver grains marked the localisation of the ${ }^{125}$ I-ET-1 binding to the ETA receptors. In the sections of the con- 

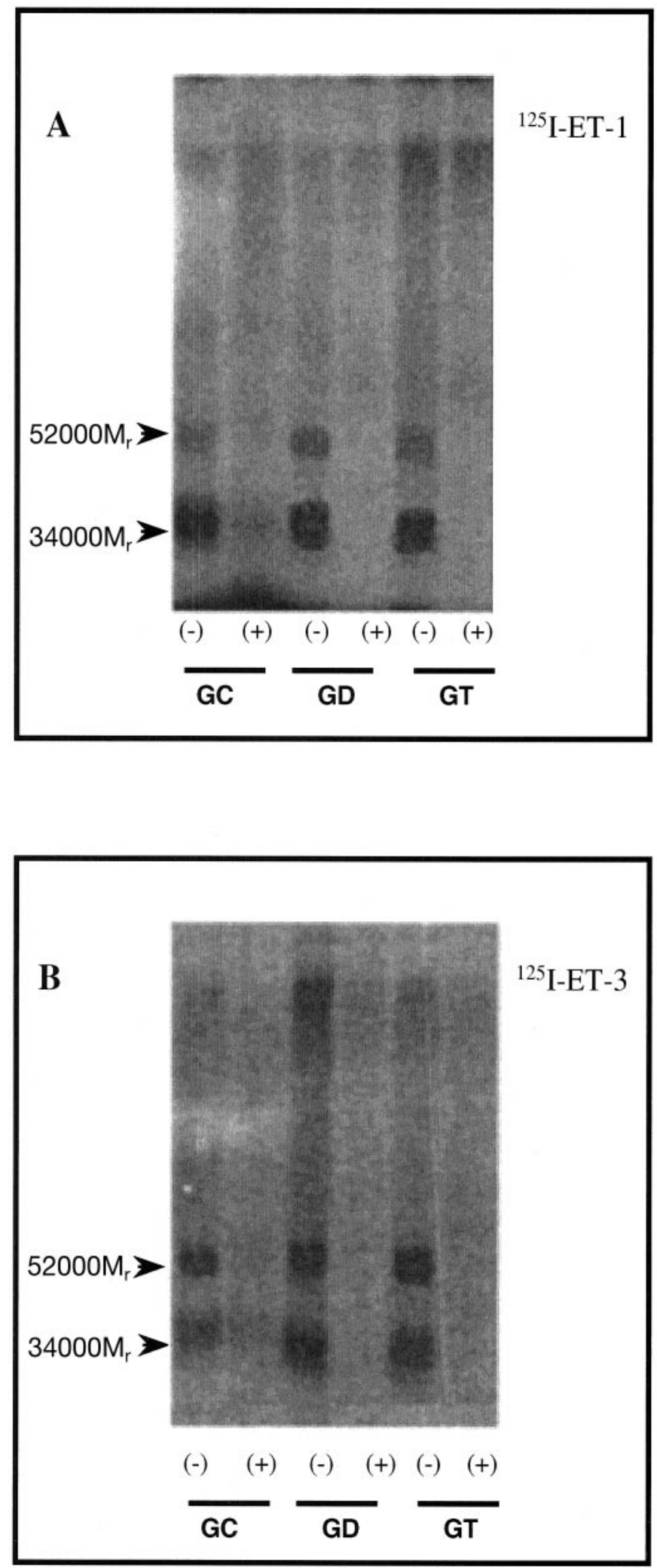

Fig. 5. Autoradiogram of SDS-PAGE of cross-linked ET receptors in neural retinal membranes from control (GC), untreated STZ-diabetic (GD) and insulin-treated STZ-diabetic (GT) rats. Membrane preparations were incubated with either ${ }^{125}$ I-ET-1 (A) or ${ }^{125}$ I-ET-3 (B) in the absence $(-)$ or presence ( + ) of $0.1 \mu \mathrm{mol} / 1 \mathrm{ET}-1$ or $0.1 \mu \mathrm{mol} / \mathrm{l}$ ET-3, respectively. Similar results were obtained in three separate experiments trol rats, the silver grains appeared diffuse and homogeneously distributed on all the retinal layers. Similar distribution is observed in the sections from untreated STZ-diabetic rats. In contrast, in the sections from insulin-treated STZ-diabetic rats a dense band of silver grains appeared extending from IN to GCL.

In the sections incubated with the ${ }^{125}$ I-ET-1 in the presence of $1 \mu \mathrm{mol} / \mathrm{l} \mathrm{BQ123} \mathrm{(Fig} 6 \mathrm{E}, \mathrm{J}, \mathrm{O}$ ) the silver grains marked the localisation of the ETB receptors. In the sections from control and untreated STZdiabetic rats, the labelling was diffuse on the ON, the IN and the RCL layers, whereas on the GCL dense clouds of silver grains appeared. In the sections from the insulin-treated STZ-diabetic rats, a diffuse covering of grains was observed in all retinal layers without the clusters of silver grains that were observed on the GCL from the retinas of the other two group of rats.

Microautoradiography of ${ }^{125}$ I-ET-3 binding sites (Fig.7): in the sections from the three groups of animals, labelling (Fig.7A,D,G) appeared mainly on the innermost layers of the retinas (IN, IPL and GCL). The sections from the untreated STZ-diabetic rats showed a higher density of silver grains on the innermost layers of the retinas than in the age-matched control and the insulin-treated STZ-diabetic animals. The binding was specific, since $0.1 \mu \mathrm{mol} / 1 \mathrm{ET}-3 \mathrm{re}-$ duced the labelling to background levels (Fig. 7B,E,H). The presence of $0.1 \mu \mathrm{mol} / 1 \mathrm{~S} 6 \mathrm{c}$ (Fig. 7C,F,I) also prevented the apparition of silver grains in the sections from the three groups of rats, indicating that the labelled hormone binds mainly to the ETB recep-

Fig. 6. Microautoradiographic localisation of ${ }^{125}$ I-ET-1 binding sites in consecutive sections from control (B-E), untreated STZ-diabetic (G-J) and insulin-treated STZ-diabetic (L-O) rat retinas 90 days after the induction of diabetes. All sections were incubated with ${ }^{125}$ I-ET-1 $40 \mathrm{pmol} / \mathrm{l}$. Sections incubated in the absence of unlabelled ligands $(\mathbf{B}, \mathbf{G}, \mathbf{L})$ showed the localisation of total ET-1 binding sites (ETA + ETB receptors). The incubations of the sections in the presence of $0.1 \mu \mathrm{mol} / 1$ ET-1 (C, H, M) showed negligible background. In the sections incubated in the presence of $0.1 \mu \mathrm{mol} / 1 \mathrm{~S} 6 \mathrm{c}(\mathbf{D}, \mathbf{I}, \mathbf{N})$ the silver grains marked the distribution of ETA receptors while in the sections incubated in the presence of $1 \mu \mathrm{mol} / \mathrm{l} \mathrm{BQ} 123(\mathbf{E}, \mathbf{J}$, O) the silver grains showed the presence of ETB receptors. At the top of each dark-field image appears a graph showing the optical density profile corresponding to a perpendicular line marked across the retina. Each one of the three profiles belongs to an independent experiment, the thickest line represents the optical density obtained on the white marked line of the dark-field photography. There was a similarity between the three profiles, indicating that the results obtained in the three experiments were similar. Bright-field images $(\mathbf{A}, \mathbf{F}, \mathbf{K})$ correspond to the sections incubated in the absence of unlabelled ligands $(\mathbf{B}, \mathbf{G}, \mathbf{L})$ counterstained with toluidine blue (S, sclera; Ch, choroid; RCL, rods and cones layer; ON, outer nuclear layer; IN, inner nuclear layer; IPL, inner plexiform layer; GCL, ganglion cell layer). (Original magnification $\times 80$ ) 
A
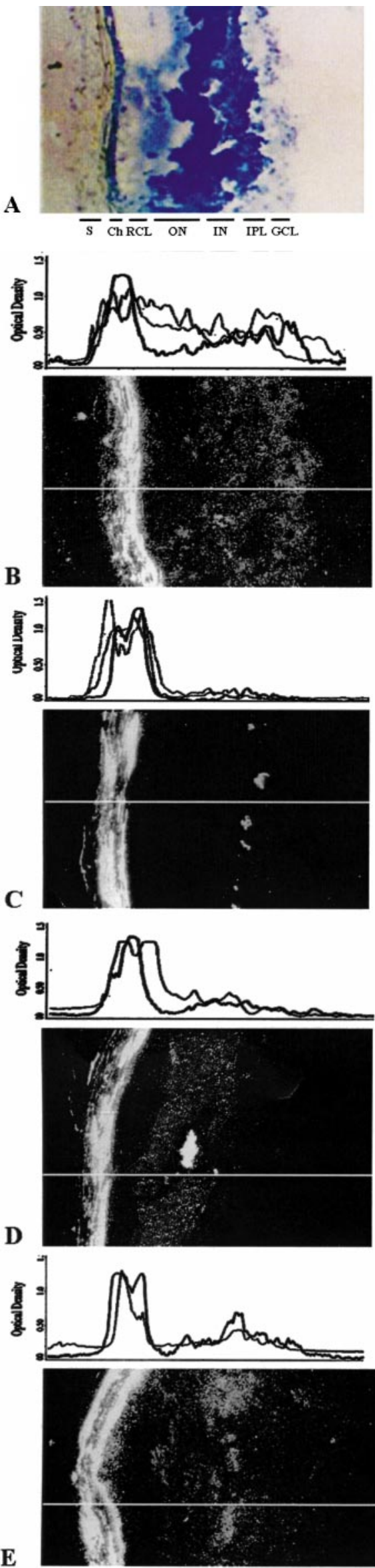

F
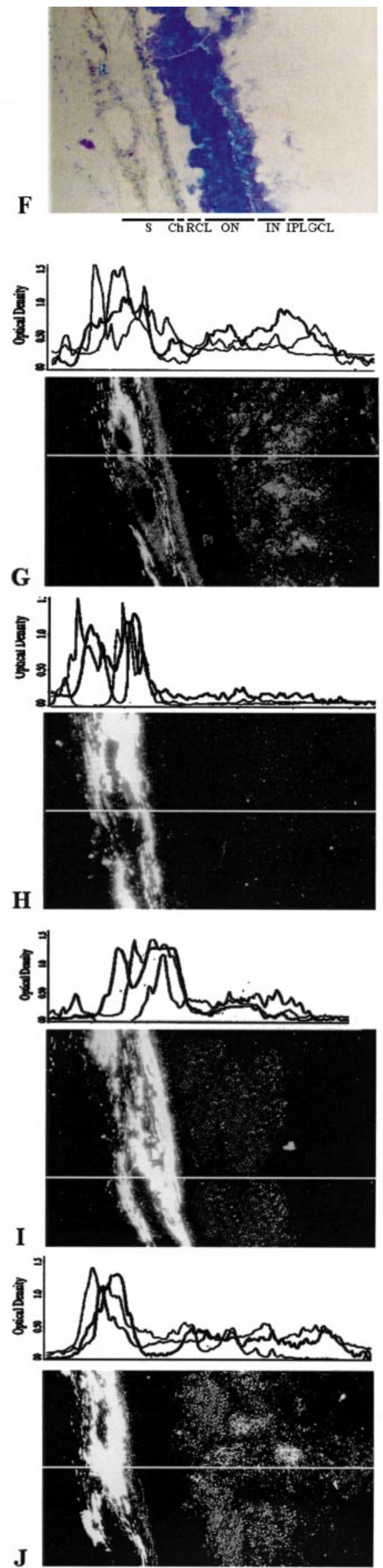
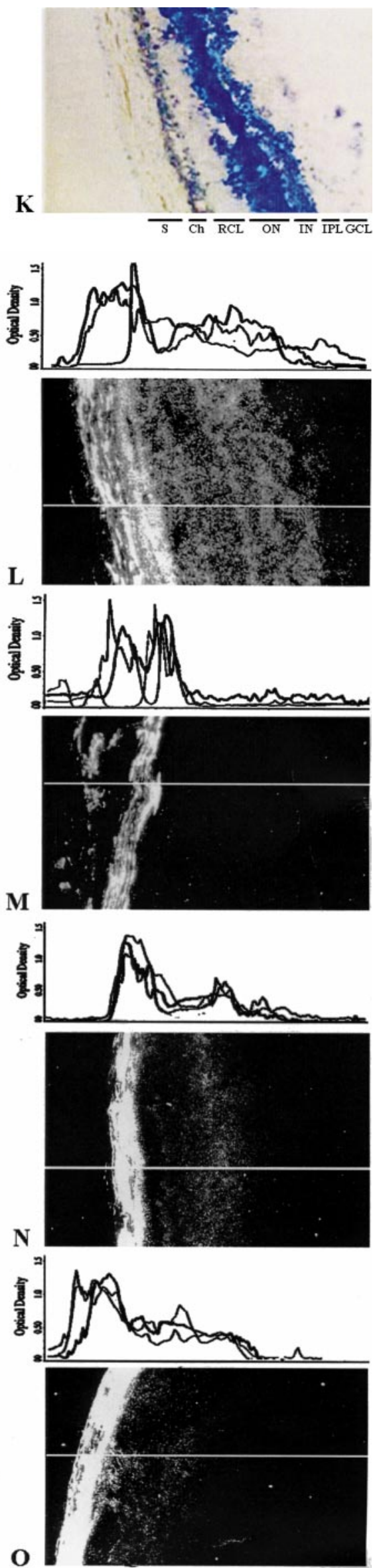
tor. These results also show that ${ }^{125}$ I-ET-3 at the concentration of $40 \mathrm{pmol} / \mathrm{l}$ mainly binds to the ETB receptors.

In addition, binding, microautoradiographic and immunohistochemical studies were done in retinas from rats that received STZ but remained normoglycaemic. The results obtained were similar to those of control rats, indicating that STZ injection did not affect the ET system (data not shown).

\section{Discussion}

In this study we have shown that the induction of diabetes caused time-dependent alterations in the density of both ETA and ETB receptors in neural retinal membranes and in the innermost layers of the retinas accompanied by an increase in the presence of IRET-1. Insulin treatment during 90 days up-regulated ETA receptors when compared with control retinas.

A tight coupling exists between neural activity and blood flow in the nervous tissues. When neuronal activity increases, an increment in the local blood flow occurs until normal homeostasis is re-established [33]. In the retina, the nerve fibres and processes from the neurones and the glial cells surround the vessels, putatively for the adjustment of the blood flow to neural function [33, 34]. As ETs are present in the neural retina $[35,11]$, it is possible that these peptides might regulate the retinal blood flow, acting on its receptors present on neurones and glial cells in addition to their direct effect on the retinal vessels. Moreover, in the early stages of diabetes, the retinal blood flow is altered and it has been proposed that ET-1 possibly contributes to these alterations [17, 20]. Thus, we have studied the effect of experimental diabetes on the ET system in neural retinal tissue.

The membrane preparations used in the binding assays were free of vascular contamination as shown by the absence of factor VIII, an endothelial marker. We have reported previously about the presence of ETA and ETB receptors in the neural retinal membranes from normal rats [11]. Only ETB receptors were detected in membranes from human cerebral cortex prepared in a similar way [36], thereby omitting contamination by ETA receptors present in the vasculature of this tissue [37]. We can thus assert that our retinal membrane preparations contain only neural components.

Our binding results indicate that 15 days after the induction of diabetes, the densities of ETA and ETB receptors in the neural retinal membranes of untreated STZ-diabetic rats were lower than in those of agematched control rats. A similar decrease was found 3 days after the injection of STZ in rat heart membranes [38]. On the other hand, a reduced response to exogenous ET-1 was observed in the diabetic retina which also indicates abnormalities of the ET sys- tem in the retina of rats with short duration of diabetes [17]. The diminution of ET receptors, probably due to a down-regulation mechanism in response to an increase in retinal expression of ET-1, might contribute to the reduction of retinal blood flow observed at this stage of diabetes [20,39]. Furthermore, in the time period between 15 and 90 days, we have observed a statistically significant increment of the density of ETB receptors in the neural retinal membranes of the untreated STZ-diabetic rats. In contrast, an increase of both ETA and ETB mRNAs has been reported in the whole retina of 6-month-old spontaneously diabetic $\mathrm{BB} / \mathrm{W}$ rats compared with age-matched control rats [13]. This discrepancy is possibly due to the different animal model and age and to the simultaneous analysis of both vascular and neuronal ET receptors in that author's study. The retinal blood flow is known to decrease in the early stages of diabetes, and it has been proposed that an up-regulation of ET-1 could be the principal cause $[17,20]$. Therefore, the increase of the ETB receptor density in diabetes could represent a compensatory mechanism of the nervous cells of the retina to the reduced retinal blood flow since ETB stimulates the production of NO $[1,40]$, a factor which induces vasodilatation of the retinal vessels [41]. Another possible explanation is that augmented ETB might act as a clearance receptor in the removal of the excess ET-1 present in the diabetic tissues [9].

Microautoradiographic studies showed that the binding sites for ${ }^{125}$ I-ET-1 and ${ }^{125}$ I-ET-3 appear on all the rat retinal layers, although the labelling was more intense in the innermost ones. The presence of IR-factor VIII-related antigen signal corroborated that those layers are the most vascularised in the retina. Using S6c and BQ123, we also observed that the ETB receptor is more abundant than the ETA in all layers of the retina. In agreement, it has been previously reported that in human and rat eyes the ETA receptors were associated with the retinal and choroidal blood vessels, whereas the ETB receptors were located mainly on the neurones or glial cells, or both, of the retina $[15,16]$. The sections from untreated STZ-diabetic rats at 90 days after STZ injection showed a pattern of ${ }^{125}$ I-ET-1 receptor distribution similar to that of age-matched control rats. The innermost layers of the diabetic retina, however, evidenced a greater density of ETB receptors in comparison with the control sections. In agreement with the binding experiments, these results suggest that diabetes induces an up-regulation of ETB receptors in the retina 90 days after the induction of diabetes.

The densities of both ${ }^{125}$ I-ET- 1 and ${ }^{125}$ I-ET- 3 binding sites in neural retinal membranes from insulin treated STZ-diabetic rats on day 15 were similar to those of the age-matched control animals. Insulin treatment during 90 days, however, increased the ETA receptors in the neural retina as well as within 

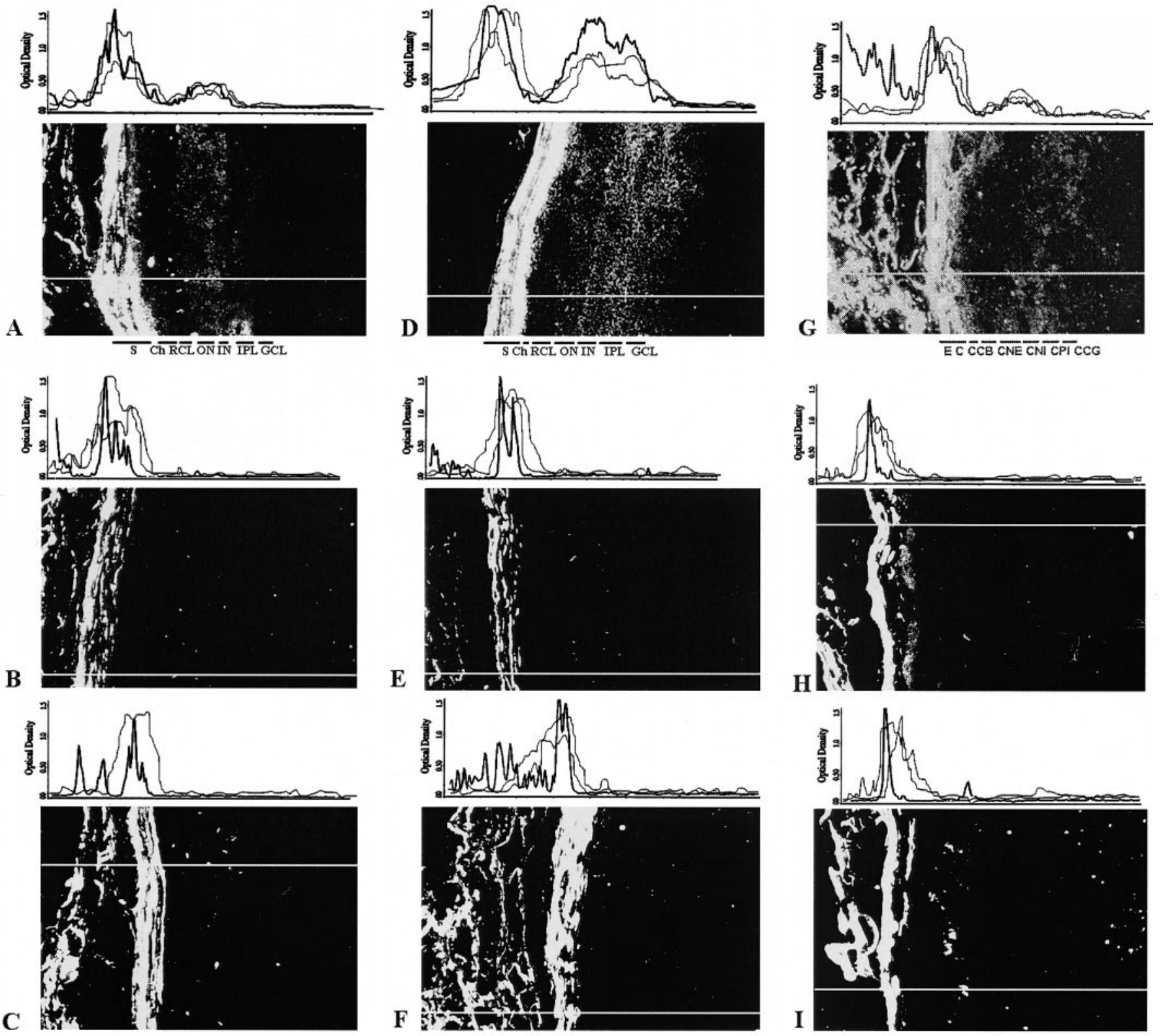

Fig. 7. Dark-field images showing microautoradiographic localisation of ${ }^{125}$ I-ET-3 binding sites in consecutive sections from control (A-C), untreated STZ-diabetic (D-F) and insulin-treated STZ-diabetic (G-I) rat retinas 90 days after the induction of diabetes. Sections were incubated with $40 \mathrm{pmol} / 1$ ${ }^{125}$ I-ET-3 in the absence of unlabelled ligand $(\mathbf{A}, \mathbf{D}, \mathbf{G})$ or in the presence of either $0.1 \mu \mathrm{mol} / 1 \mathrm{ET}-3(\mathbf{B}, \mathbf{E}, \mathbf{H})$ or $0.1 \mu \mathrm{mol} / 1$ S6c $(\mathbf{C}, \mathbf{F}, \mathbf{I})$. At the top of each dark-field image appears a graph showing the optical density profile corresponding to a perpendicular line marked across the retina. Each one of the three profiles belongs to an independent experiment, the thickest line represents the optical density obtained on the white marked line of the dark-field photography. There was a similarity between the three profiles, indicating that the results obtained in the three experiments were similar $(\mathrm{S}$, sclera; $\mathrm{Ch}$, choroid; RCL, rods and cones layer; ON, outer nuclear layer; IN, inner nuclear layer; IPL, inner plexiform layer; GCL, ganglion cell layer). (Original magnification $\times 80$ ) the innermost layers of the retina in comparison with age-matched control retina. These alterations could be directly due to the injected insulin, since this hormone increases the ETA receptor mRNA expression in vivo and in vitro [22] or indirectly to the metabolic improvement. The up-regulated ETA receptor could trigger an increase in the mitotic activity of retinal cells since this receptor is implicated in the stimulation of the mitogenesis in a number of cells, including the glial cells [3]. Moreover, the ETA receptor increment found here could be implicated in the reduction of the number of apoptotic cells observed in the neural retina of insulin-treated STZ-diabetic rats in comparison with those of untreated STZ-diabetic rats [42]. The potential effect and the long-term consequences of augmented ETA in the retina are still not known.

Diabetes up-regulated the IR-ET-1 signal in almost all layers of the retina from untreated STZ-dia- 
betic rats 90 days after the induction of diabetes in comparison with age-matched control rat retina. This effect could be due to either an extravasation in the retina of the high plasmatic ET-1 concentrations that we found at 90 days or to an increment of ET-1 synthesis in the retinal cells. In agreement, in ocular tissues of diabetic rats increased concentrations of IR-ET-1 have been shown [43]. This alteration, partially reversed by insulin treatment, could be due to hyperglycaemia that activates protein kinase $\mathrm{C}$, initiating a pathway competent for increased ET-1 gene expression [44].

The changes in the ET receptor density are not due to alterations in the vascularisation of the retina since the factor VIII-related antigen evidenced a similar distribution in the retina of the three groups of animals. The absence of neovascularisation in the retina of STZ-diabetic rats has already been reported by other authors [45]. On the other hand, the changes in ET receptors are not also due to the occurrence of a new type of ET binding sites in the diabetic retina since the patterns of labelled bands in the cross-linking experiments were the same in the three groups of rats.

The alterations that we observed in the ET system were not caused by the injection of STZ since no statistically significant differences in density and localisation of both ETA and ETB receptors and IR-ET-1 were observed in retinas from rats that remained normoglycaemic despite injection of STZ.

An interesting observation was that the density of ET receptors in the neural rat retina decreased with age mainly due to a reduction of the number of ETB receptors. Although the factors responsible for this age-dependent alteration and their physiologic significance are not known, we think they could be related to the neuronal and glial cell loss in the retina during the ageing process $[46,47]$. The disappearance of cells in the retina with age is mainly due to apoptosis of some cell populations and probably constitutes the basis for ocular ageing and visual loss.

In summary, changes of both the neural and vascular ET system in the rat retina were observed in the early stages of diabetes which might have a functional relevance to the development of diabetic retinopathy. The up-regulation of retinal ETA produced by insulin treatment could be an important factor in the pathogenesis of retinal microangiopathy in diabetes.

Acknowledgements. This work was supported by grants from DGICYT (PB92-0737) and DGESIC (PM97-0028). We thank Dr I. Valverde for the determinations of plasmatic IR-insulin.

\section{References}

1. Yanagisawa M, Kurihara H, Kimura S et al. (1988) A novel potent vasoconstrictor peptide produced by endothelial cells. Nature 332: 411-415

2. Inoue A, Yanagisawa M, Kimura S et al. (1989) The human endothelin family: three structurally and pharmacological- ly distinct isopeptides predicted by three separate genes. Proc Natl Acad Sci USA 86: 2863-2867

3. Battistini B, Chailler P, D'Orleans-Juste P, Brière N, Sirois P (1993) Growth regulatory properties of endothelins. Peptides 14: 385-399

4. Arai H, Hori S, Aramori I, Ohkubo H, Nakanishi S (1990) Cloning and expression of a cDNA encoding an endothelin receptor. Nature 348: 730-732

5. Sakurai T, Yanagisawa M, Takuwa Y et al. (1990) Cloning of a cDNA encoding a non isopeptide selective subtype of endothelin receptor. Nature 348: 732-735

6. Sakurai T, Yanagisawa M, Masaki T (1992) Molecular characterisation of endothelin receptor. Trends Pharmacol Sci 13: 103-108

7. Warner TD, Mitchell JA, de Nucci G, Vane JR (1989) Endothelin-1 and endothelin-3 release EDRF from isolated perfused arterial vessel of the rat and rabbit. J Cardiovas Pharmacol 13: S85-S88

8. Seo B, Oemar BS, Siebenmann R, von Segesser L, Luscher TF (1994) Both ETA and ETB receptors mediate contraction to endothelin-1 in human blood vessels. Circulation 89: $1203-1208$

9. Fukuroda T, Fujikawa T, Ozaki S, Ishikawa K, Yano M, Nishikibe M (1994) Clearance of circulating endothelin-1 by ETB receptors in rats. Biochem Biophys Res Commun 199: 1461-1465

10. MacCumber MW, Jampel HD, Snyder SH (1991) Ocular effect of endothelin. Arch Ophtalmol 109: 705-709

11. De Juan JA, Moya FJ, Fernandez-Cruz A, Fernandez-Durango $\mathrm{R}$ (1995) Identification of receptor subtypes in rat retina using subtype-selective ligands. Brain Res 690: 25-33

12. De Juan JA, Moya FJ, Garcia de la Coba M, FernándezCruz A, Fernández-Durango R (1993) Identification and characterisation of endothelin receptor subtype $\mathrm{B}\left(\mathrm{ET}_{\mathrm{B}}\right)$ in rat retina. J Neurochem 61: 1113-1119

13. Chakrabarti S, Gan XT, Merry A, Karmazyn M, Sima AA (1998) Augmented retinal endothelin-1, endothelin-3, endothelin A and endothelin B gene expression in chronic diabetes. Curr Eye Res 17: 301-307

14. Wollensak G, Schaefer HE, Ihling Ch (1998) An immunohistochemical study of endothelin-1 in the human eye. Curr Eye Res 17: 541-545

15. Sitt AW, Chakravarthy U, Gardiner TA, Archer DB (1995) Endothelin-like immunoreactivity and receptor binding in the choroid and retina. Curr Eye Res 15: 111-117

16. McCumber MW, D'Anna SA (1994) Endothelin receptorbinding subtypes in the human retina and choroid. Arch Ophtalmol 112: 1231-1235

17. Bursell S-E, Clermont AC, Oren B, King GL (1995) The in vivo effect of endothelins on retinal circulation in nondiabetic and diabetic rats. Invest Ophtalmol Vis Sci 36: 596-607

18. Bursell S-E, Clermont AC, Shiba T, King GL (1992) Evaluating retinal blood flow using video fluorescein angiography in control and diabetic rats. Curr Eye Res 11: 287-295

19. Cringle SJ, Yu D-Y, Alder VA, Su E-N (1993) Retinal blood flow by hydrogen clearance polarography in the streptozotocin-induced diabetic rats. Invest Ophthalmol Vis Sci 34: 1716-1721

20. Takagi C, Bursell S-E, Lin Y-W et al. (1996) Regulation of retinal hemodynamics in diabetic rats by increased expression and action of endothelin-1. Invest Ophthalmol Vis Sci 37: 2504-2518

21. Oliver FJ, De la Rubia G, Feener EP et al. (1991) Stimulation of endothelin 1 gene expression by insulin in endothelial cells. J Biol Chem 266: 23251-23256 
22. Frank HJ, Levin ER, Hu R-M, Pedram A (1993) Insulin stimulates endothelin binding and action on cultured vascular smooth muscle cells. Endocrinology 133: 1092-1097

23. Hopfner RL, Hasnadka RV, Wilson TW, McNeil JR, Gopalakrishnan V (1998) Insulin increases endothelin-1evoked intracellular free calcium responses by increased ETA receptor expression in rat aortic smooth muscle cells. Diabetes 47: 937-944

24. Clermont AC, Brittis M, Shiba T, McGovern T, King GL, Bursell S-E (1994) Normalisation of retinal blood flow in diabetic rats with primary intervention using insulin pumps. Invest Ophtalmol Vis Sci 35: 981-986

25. Higashi S, Clermont AC, Dhir V, Bursell S-E (1998) Reversibility of retinal flow abnormalities is disease-duration dependent in diabetic rats. Diabetes 47: 653-659

26. Kihara M, Low PA (1995) Impaired vasoreactivity to nitric oxide in experimental diabetic neuropathy. Exp Neurol 132: $180-185$

27. Valverde I, Barreto M, Malaisse WJ (1988) Stimulation by $\mathrm{D}$-glucose of protein biosynthesis in tumoral insulinproducing cells (RINm5F line). Endocrinology 122: 1443-1448

28. Fernández-Durango R, Sanchez D, Gutkowska J, Carrier F, Fernández-Cruz A (1989) Identification and characterisation of atrial natriuretic factor receptors in the rat retina. Life Sci 44: 1837-1846

29. Laemmli U (1970) Cleavage of structural proteins during the assembly of the head of the bacteriophage T4. Nature 227: 680-684

30. Ripodas A, De Juan JA, Moya FJ, Fernandez-Cruz A, Fernandez-Durango R (1998) Identification of endothelin receptor subtypes in rat ciliary body using subtype-selective ligands. Exp Eye Res 66: 69-79

31. Munson PJ, Rodbard D (1980) LIGAND: A versatile computerized approach for characterisation of ligand binding systems. Anal Biochem 107: 220-239

32. MacPherson GA (1985) Analysis of radioligand binding experiments: A collection of computer programs for the IBM PC. J Pharmacol Meth 14: 213-224

33. Lou HC, Edvinsson L, MacKenzie ET (1987) The concept of coupling blood flow to brain function: revision required? Ann Neurol 22: 289-297

34. Mizutani M, Gerhardinger C, Lorenzi M (1998) Müller cell changes in human diabetic retinopathy. Diabetes 47: 445-449

35. McCumber MW, Ross CA, Glasser BM, Snyder SH (1989) Endothelin: visualisation of mRNAs by in situ hybridiza- tion provides evidence for local action. Proc Natl Acad Sci USA 86: 7285-7289

36. Fernandez-Durango R, de Juan JA, Zimman H, Moya FJ, Garcia de Lacoba M, Fernandez-Cruz A (1994) Identification of endothelin receptor subtype $\left(\mathrm{ET}_{\mathrm{B}}\right)$ in human cerebral cortex using subtype-selective ligands. J Neurochem 62: 1482-1488

37. Harland SP, Kuc RE, Pickard JD, Davenport AP (1998) Expression of endothelin(A) receptors in human gliomas and meningiomas, with high affinity for the selective antagonist PD156707. Neurosurgery 43: 890-899

38. Nayler WG, Liu J, Panagiotopoulos S, Casley DJ (1989) Streptozotocin-induced diabetes reduces the density of 125I-ET-1-binding sites in rat cardiac membranes. Br J Pharmacol 97: 993-995

39. Ramachandran E, Frank RN, Kennedy A (1993) Effects of endothelin on culture bovine retinal microvascular pericytes. Invest Ophthalmol Vis Sci 34: 586-595

40. De Nucci G, Thomas R, D’Orleans Juste P et al. (1990) Pressor effects of circulating endothelin are limited by its removal in the pulmonary circulation and by the release of prostacyclin and endothelium derived relaxing factor. Proc Natl Acad Sci USA 85: 9797-9800

41. Deussen A, Sonntag M, Vogel R (1993) L-arginine-derived nitric oxide: a major determinant of uveal blood flow. Exp Eye Res 57: 129-134

42. Barber AJ, Lieth, E, Khin SA et al. (1998) Neural apoptosis in the retina during experimental and human diabetes. J Clin Invest 102: 783-791

43. Chakravarthy U, Hayes RG, Stitt AW, Douglas A (1997) Endothelin expression in tissues of diabetic and insulintreated rats. Invest Ophtalmol Vis Sci 38: 2144-2151

44. Shiba T, Inoguchi T, Sportsman JR, Heath WF, Bursell S-E, King GL (1993) Correlation of diacylglycerol level and protein kinase $\mathrm{C}$ activity in rat retina to retinal circulation. Am J Physiol 265: E783-E793

45. Hammes H, Lin J, Bretzel R, Brownlee M, Breier G (1998) Upregulation of the vascular endothelial growth factor/ Vascular endothelial growth factor receptor system in experimental background diabetic retinopathy of the rat. Diabetes 47: 401-406

46. Weisse I, Loosen H, Peil H (1990) Age-related retinal changes-comparison between albino and pigmented rats. Lens Eye Toxic Res 7: 717-719

47. O'Steen WK, Brodish A (1990) Scleral calcification and photoreceptor cell death during ageing and exposure to chronic stress. Am J Anat 189: 62-68 